„Ante Portas - Studia nad Bezpieczeństwem”

2019, $\mathrm{Nr} 2(13)$

DOI: $10.33674 / 201915$

\title{
Wiktor MOŻGIN
}

Polska

\section{ANNA BAEDYGA, ZNACZENIE EKSPORTU GAZU ZIEMNEGO W POLITYCE GOSPODARCZEJ FEDERACJI ROSYJSKIEJ, WYDAW- NICTWO WSBIP, OSTROWIEC ŚWIĘTOKRZYSKI 2019, SS. 287}

Monografia naukowa dotykająca czynników wzrostu gospodarczego, a w szczególności rozwoju napędzanego przez eksport surowców, jest jedną z bardziej wyczekiwanych wśród badaczy zajmujących się tą tematyką. W tym kontekście obszar tematyczny pracy spełnia niejako podwójną rolę.

$\mathrm{Z}$ jednej strony bardzo mocno akcentuje aspekty współczesnej teorii ekonomii, podejmując polemikę $\mathrm{z}$ ugruntowanym powszechnie poglądem na temat charakteru możliwych czynników wzrostu gospodarczego w XXI w. Powtórne wprowadzenie pod dyskusję czynników o charakterze surowcowym, wobec licznych przykładów z praktyki, potwierdzających tezę o przekleństwie bogactw naturalnych - mogło wydawać się zadaniem karkołomnym. Niemniej jednak autorka poradziła sobie z nim w sposób satysfakcjonujący. Monografia ma solidną podstawę teoretyczną, a poprawnie użyte metody badawcze i precyzyjne przedstawienie wzajemnych zależności badanych zjawisk oraz ich tła, pozwoliły na uzyskanie i zaprezentowanie wniosków podważających sceptycyzm współczesnych ekonomistów w kwestii roli surowców w rozwoju gospodarczym poszczególnych krajów. Fakt ten wpłynie na odświeżenie dyskusji w tym obszarze oraz nadanie badaniom naukowym nowego kierunku.

$\mathrm{W}$ tym znaczeniu rola publikacji jest $\mathrm{w}$ zasadzie nie do przecenienia. Drugim aspektem wartym podkreślenia $\mathrm{w}$ obszarze podjętej $\mathrm{w}$ monografii tematyki, jest jej, chwilami uderzająca, aktualność i silny wpływ na szereg innych czynników. Eksport surowców energetycznych z Rosji jest głęboko związany $\mathrm{z}$,antyliberalnym” modelem władzy państwowej w tym kraju, upolitycznieniem życia publicznego, bezpieczeństwem energetycznym państw Unii Europejskiej, globalną polityką klimatyczną oraz (a może przede wszystkim) z ogniskami zapalnymi i konfliktami zbrojnymi w różnych zakątkach współczesnego świata. Autorka monografii z dużą dozą sprawności porusza powyższe wątki, otwierając każdorazowo nową perspektywę rozumienia tematu i szerokie pole do dalszych rozważań. Jednocześnie jest $\mathrm{w}$ swym stylu pisania na tyle zdyscyplinowana, by zanadto nie odbiegać od 
głównego wątku, jakim jest wymiar gospodarczy eksportu rosyjskiego gazu, co jest wyraźnie podkreślone w pracy. Ta wielowątkowość oraz częste odwoływanie się do najnowszych wydarzeń, znanych raczej z przekazów medialnych niż $\mathrm{z}$ naukowych opracowań, czynią lekturę monografii dodatkowo interesującą.

Badając temat autorka bardzo sprawnie korzysta $\mathrm{z}$ różnorodnych metod badawczych. Wybrane metody są użyte zgodnie $\mathrm{z}$ ich założeniami, a poszczególne fazy prezentowanych analiz mają poprawny przebieg. W pracy widać umiejętność właściwego doboru i selekcji materiałów źródłowych, logiczne wyprowadzanie wniosków oraz właściwe kojarzenie różnych aspektów problemu - charakterystyczne dla samodzielnych badaczy. Na wyróżnienie zasługuje wykorzystanie metod ekonometrycznych, w tym wektorowego modelu korekty błędem (VECM). Autorka nie tylko w przystępny sposób prezentuje, wieloetapowy proces analizy, lecz także poprzedza całą prezentację wyników wstępem, wskazującym na szerokie wykorzystanie wybranej metody w badaniu problematyki wpływu eksportu surowców na wzrost gospodarczy. Wstęp ten dopełnia wniosków z części badawczej.

Oceniając tę publikację warto nadmienić szeroki dobór literatury w trzech językach, co pozwoliło zobiektywizować uzyskiwane informacje. Ma to szczególne znaczenie przy badaniu kondycji społeczno-gospodarczej Rosji kraju, w którym wolność słowa oceniana jest bardzo słabo, a zjawisko autocenzury wśród dziennikarzy i naukowców jest dosyć powszechne. Autorka odwołuje się do szeregu tekstów źródłowych, w tym aktów prawnych, w ich oryginalnym brzmieniu. Wnioski z analizy materiałów zestawiane są z danymi statystycznymi, prezentowanymi przez uznane, w skali globalnej, ośrodki badawcze. Dają one jednoznaczne i wiarygodne rezultaty, poparte dodatkowo obszernie przytaczanymi publikacjami naukowymi. Zarzutem w tym punkcie mogłoby być wskazanie na dosyć szerokie, jak na standardy publikacji naukowej, wykorzystanie materiałów publicystycznych. Biorąc jednak pod uwagę wysoką aktualność tematyki oraz solidną podstawę naukową pracy, fakt wykorzystania publikacji dziennikarskich w monografii można uznać za ciekawostkę, dopełniającą prezentowanych analiz, bądź też swoisty kontrapunkt dla mocniej ugruntowanych publikacji naukowych. Przy czym należy mieć świadomość, że tak niedawne wydarzenia jak te opisywane w monografii - faktycznie nie doczekały się jeszcze naukowych opracowań.

Język, użyty w monografii, ma charakter formalny. Słownictwo i wyrażenia fachowe, typowe dla prac o charakterze ekonomicznym, są prawidłowo używane. Autorka posługuje się nimi nie tylko świadomie, ale też i swobodnie, co świadczy o jej dojrzałości badawczej. Pomimo licznych zwrotów ekonomicznych, monografia jest pisana przystępnym językiem, ułatwiającym odbiór osobom nie mającym wykształcenia ekonomicznego. 
Kwestią zasługującą na osobną wzmiankę, jest dobór okresu badawczego (2000-2013). Z jednej strony jest on bardzo krótki, jak na standardy wybranej metody ekonometrycznej, czego autorka ma świadomość. $Z$ drugiej, skomplikowana historia i sytuacja geopolityczna Rosji nie pozwalała wydłużyć badanego okresu ani o burzliwe lata 90 . XX w. ani też o kolejne lata tj. 20142019, w związku z radykalną zmianą sytuacji po aneksji Krymu. Jednak te niesprzyjające okoliczności oraz brak wyrazistych wyników w pierwotnych badaniach nie powstrzymały autorki. Rozszerzyła ona bowiem liczbę analizowanych czynników także o ropę naftową. Pozwoliło to pozytywnie zweryfikować postawione w monografii hipotezy badawcze. W tym miejscu należy wskazać niedoskonałość pracy, polegającą na braku, choćby skrótowego, przedstawienia charakterystyki rynku ropy naftowej w Rosji.

W monografii autorka stawia 1 hipotezę główną oraz 4 pomocnicze. Wszystkie one sformułowane są w sposób prawidłowy. W toku pracy hipotezy te są kilkukrotnie weryfikowane przy wykorzystaniu odrębnych metod badawczych, co dodatkowo uwiarygadnia wyniki prezentowanych analiz.

Pierwszy rozdział pełni rolę szerokiego wstępu teoretycznego do problematyki monografii. Odwołuje się do licznych przykładów współczesnej teorii ekonomii prezentując aktualne podejście ekonomistów nie tylko w kwestii zagadnienia czynników wzrostu gospodarczego czy teorii wzrostu napędzanego przez eksport. Autorka poszerza obszar badań teoretycznych m.in. o problematykę monopolu, własności surowców mineralnych czy też trwałego cofnięcia gospodarczego - co przy ograniczonej objętości publikacji, należy uznać za jej dodatkowy atut. Na pewno nie udało się zawrzeć dorobku badawczego na temat czynników wzrostu w sposób wyczerpujący, jednak autorka zestawia kluczowe teorie w sposób prawidłowy, co w rezultacie umożliwiło jej zrealizowanie celu, jakim było pokazanie aktualnego stanu wiedzy w prezentowanym zagadnieniu.

Rozdział drugi miał za zadanie nakreślić tło społeczno-gospodarcze dla przedmiotu prowadzonych badań. Autorka podjęła się próby wyselekcjonowania głównych reform w Rosji w okresie badawczym, co stanowiło niełatwe zadanie. Poszczególne akty prawne prezentowane są $\mathrm{W}$ sposób logiczny i uporządkowany, ale też dosyć szczegółowy, jak na wątek poboczny w toku pracy. Zaprezentowano kondycję gospodarczą Rosji w pierwszych dwóch dekadach XXI w. oraz kondycję ekonomiczną kluczowego gracza na rynku gazu - Gazpromu. Całość wzbogacono o szczegółową analizę kondycji społecznej narodu rosyjskiego. Autorka z dużą dozą dociekliwości porównuje wartości poszczególnych wskaźników, wyrażających poziom życia i dobrobytu wśród Rosjan z wartościami ich odpowiedników dla krajów Europy Zachodniej. Atutem tego rozdziału jest połączenie i całościowa interpretacja prezentowanych wątków.

Trzeci rozdział jest prezentacją wyników analizy badawczej. Wstęp do rozdziału stanowi opis metody i przykłady jej zastosowania w badaniu wpływu 
eksportu surowców na wzrost gospodarczy innych krajów, co w znacznym stopniu uwiarygadnia metodę badawczą obraną przez autorkę. Opis metody jest precyzyjny i klarowny, co powoduje, że nawet osoby mniej biegłe w temacie budowy modeli ekonometrycznych mogą przyswoić i zrozumieć ten aspekt pracy. Zarówno dobór metody jak i prezentacja wyników analizy - są prawidłowe. Autorka uzyskuje pierwotnie niejednoznaczne rezultaty, jednak wzbogacenie badań o dodatkowy czynnik, jakim jest eksport ropy naftowej, pozwoliły na dobitne potwierdzenie stawianych we wstępie hipotez badawczych. Podsumowując, część badawcza pracy stanowi najcenniejszy element monografii, jest również bazą do dalszych badań i rozważań naukowych, w tematyce czynników wzrostu gospodarczego.

Kolejny, czwarty rozdział ukazuje perspektywę Unii Europejskiej głównego odbiorcy gazu z Rosji. Autorka podejmuje się analizy kierunków dostaw, form surowca oraz formuł cenowych, według których kraje europejskie zaspokajają swoje rosnące zapotrzebowanie na gaz ziemny. Szczególną wagę przykłada do krajów Europy Środkowo-Wschodniej, które bardzo często są niemalże całkowicie uzależnione od dostaw surowców energetycznych. W tym rozdziale bardzo wyraźnie zarysowują się elementy praktyk monopolistycznych Gazpromu, działania liberalizacyjne organów Unii Europejskiej, handel energią $\mathrm{w}$ ramach UE oraz próba zastąpienia $\mathrm{w}$ gospodarce tradycyjnych paliw kopalnych przez odnawialne źródła energii. Autorka zarysowuje pozycję i postępy Polski we wszystkich tych aspektach, akcentując trudności negocjacyjne w zakresie kontraktów z Gazpromem. Ciekawym wątkiem pobocznym, zasługującym na wyróżnienie, jest ukazanie alternatywnego kierunku dostaw gazu do Azji. Duże zapotrzebowanie Chin na surowce i rosnące możliwości ekonomiczne tego kraju powodują, iż w niedalekiej przyszłości Europa może stracić swój priorytetowy charakter, jako główny odbiorca rosyjskiego gazu. Jest to dodatkowy walor pracy.

Ostatni, piąty rozdział, stanowi zebranie i ewaluację wszystkich dotychczasowych wniosków z prezentowanych analiz. Autorka nie poprzestaje na oszacowaniu roli eksportu gazu ziemnego w polityce gospodarczej Rosji, aktywnie poszukując alternatywnych czynników wzrostu. Ukazuje aktualny obraz innych gałęzi gospodarki, opartych o nowoczesne technologie, a które jeszcze kilka dekad temu należały do czołówki światowej, prezentując wysoki poziom i prestiż. Część prezentująca wnioski końcowe została świadomie rozdzielona na te, dotyczące polityki gospodarczej Rosji w najbliższych latach oraz na rekomendacje dla Polski, jako partnera gospodarczego Rosji oraz potencjalnego eksportera surowców na dużą skalę. Ponadto autorka zarysowuje szczegółowy plan i wytycza obszary do dalszych badań na tematem, co stanowi kolejną, bardzo dużą wartość dodaną publikacji.

Reasumując, tematyka monografii o ważkim znaczeniu dla ekonomistów zajmujących się międzynarodowymi stosunkami gospodarczymi, stanowi bazę i przyczynek do dalszych badań, rzucających światło na pytania frapujące 
wielu ekspertów. Wszystko to stanowi o wysokiej ocenie merytorycznej oraz wartości naukowej niniejszej publikacji. 